\title{
Oral Health and Self-Perception in the Elderly
}

\author{
Walda Viana Brígido de Moura1, Iris do Ceu Clara Costa², Fábia Barbosa de Andrade3, \\ Tainara Lôrena dos Santos Ferreira3 ${ }^{3}$ Andréa Silvia Walter de Aguiar1, \\ Gabriela Eugênio de Sousa Furtado', Maria Eneide Leitão de Almeida ${ }^{1}$ \\ ${ }^{1}$ Department of Dentistry, Federal University of Ceará (UFC), Fortaleza, Brazil \\ ${ }^{2}$ Department of Dentistry, Federal University of Rio Grande do Norte (UFRN), Natal, Brazil \\ ${ }^{3}$ Faculty of Health Sciences of Trairi (FACISA), Federal University of Rio Grande do Norte (UFRN), Santa Cruz, \\ Brazil \\ Email: walda viana@yahoo.com.br, iris odontoufrn@yahoo.com.br, fabiabarbosabr@yahoo.com.br, \\ tainaralorena@hotmail.com, andrea.odonto@yahoo.com.br, gabieugenio@gmail.com, \\ eneideufc@hotmail.com
}

Received 1 October 2014; revised 19 November 2014; accepted 30 November 2014

Academic Editor: Shigeru Watanabe, Department of Human Development \& Fostering, Division of Pediatric Dentistry, School of Dentistry, Meikai University, Japan

Copyright (C) 2014 by authors and Scientific Research Publishing Inc.

This work is licensed under the Creative Commons Attribution International License (CC BY). http://creativecommons.org/licenses/by/4.0/

(c) (i) Open Access

\section{Abstract}

Background: Investigating self-perception of oral health among the elderly may contribute towards changing public health and assistance policies in the area. Methods: The present study assessed the oral health status (tooth decay, need for treatment, periodontal status, use of and need for dental prosthesis, soft tissue alterations and self-perception of oral health) of 102 elderly people from two community groups in Fortaleza, Ceará State, Brazil. Results: Mean age was 69.9 years and $82.4 \%$ were female. Mean DMFT was 30.17 with a predominant missing component; $63.7 \%$ were edentulous. Regarding prosthesis, $29.4 \%$ and $67.6 \%$ of elderly patients did not use upper and lower dentures respectively, while $66.7 \%$ and $78.4 \%$ required some type of upper and lower prosthesis respectively. Among valid sextants, $44.3 \%$ presented dental calculus and $34.3 \%$ presented loss of attachment from 6 to $8 \mathrm{~mm}$. Soft tissue alterations were found in $58.8 \%$. Despite of precarious clinical conditions and dental treatment needs, good oral health perception was found (49\%), as well as satisfaction with the appearance of teeth and gums (60.8\%). Conclusion: Subjects displayed unsatisfactory oral health conditions, accumulated over time and resulting from the lack of policies favoring this age group. There is a need for oral rehabilitation that enables the recovery of function and esthetics among the elderly, restoring their self-esteem and improving social interaction. 


\section{Keywords}

\section{Oral Health, The Elderly, Epidemiology, Self-Image}

\section{Introduction}

The proportion of elderly people has grown substantially in relation to other age groups [1]. This can be attributed to demographic transition resulting from technological advances and improved standards of living, as well as a significant decrease in birth and child mortality rates, and deaths from infectious diseases. Of the various health aspects among the aged, oral health requires more care, because historically, dental services do not prioritize elderly care and because of its importance to general well being [2].

The legacy of a care model centered on curative and invasive practices has resulted in a precarious reality of missing teeth, accumulated treatment needs and a substantial demand for rehabilitative care [3]. Oral health among elderly Brazilians is currently at a critical level. In 2003, only 10\% had more than 20 of their own teeth [4], a much lower percentage than that proposed by the World Health Organization (WHO) [5], which recommended that $50 \%$ of the elderly population should have more than 20 teeth in their mouths by the year 2000 .

In accordance to the First National Oral Health Conference (I Conferência Nacional de Saúde Bucal), the expression "oral health" relates to a set of biological and psychological conditions that allow phonetic and masticatory functions to be performed. It is also associated to esthetics as it directly impacts self-esteem and social relationships without feelings of inhibition or embarrassment [6].

Self-perception in oral health includes physical and subjective elements related to the mouth and it is influenced by social and economic factors, as well as the age, gender, and social class of individuals [7] [8]. Thus, health evaluations made by patients may differ from those performed by professionals since concepts of health and disease outside of scientific knowledge, are determined exclusively by cultural values [9].

Investigating self-perception of oral health among the aged may contribute towards changing public health and assistance policies in the area. It can also enable a more effective approach by healthcare professionals, incorporating educational self-care measures and preventive, rehabilitative and curative care [8] [10].

This study aimed to assess, taking into consideration the socio-demographic and socioeconomic aspects, the oral health and the self-perception of 102 elderly participants from two community groups (CG) in Fortaleza, a state capital in Northeastern Brazil.

\section{Methods}

In this cross-sectional study, an established number of individuals are directly observed in a single encounter through analysis of each case and application of an easy-to-use and low cost questionnaire. Data collection was carried out between August 2009 and March 2010.

The present study was conducted with 50 elderly members of a CG affiliated to Federal University of Ceará (CG1), located on the outskirts of the city of Fortaleza, Ceará State, Brazil. An additional 52 subjects were participants of a CG based at the University of Fortaleza (CG2).

We evaluated a total of 102 subjects, aged 60 years or older, of any gender, both independent and partially dependent according to classifications of the Fédération Dentaire Internationale [11]. All participants were required to be members of one of the two previously mentioned CG, be present for the assessment and capable of undergoing examination. Individuals under 60 and those unable to submit to clinical evaluation were excluded.

Clinical analysis of oral health status was carried out based on the SB Brazil Project [11] undertaken by the Brazilian Ministry of Health, which was similar to WHO standards. The DMFT index was applied (mean of decayed, missing and filled teeth) to investigate the need for treatment. Periodontal condition was assessed by Loss of Attachment Index (LA) and Community Periodontal Index (CPI). The use and need of total, fixed and/or removable dentures and prevalence of soft tissue alterations was also assessed.

Data was gathered by the researchers through application of a survey containing questions on socio-demographic variables, either at the homes of participants or at the CG meetings. For socioeconomic classification, we adopted the new Standard Criteria of Economical Classification Brazil/2008 (Brazilian Association of Market Research Institutes) [12]. Concerning self-perception of oral health, questions were compiled using the na- 
tional epidemiological oral health survey—SB Brazil [4] [13].

SB Brazil is a national epidemiological survey carried out in Brazil, using a methodology adapted from the World Health Organization (WHO), which aims to build a database on the main indicators of oral health. It is the most complete diagnosis of the oral health of Brazilians, performed with a careful home-based methodology [14]. SB Ceará (epidemiological survey of the state of Ceará), whose information appears first in Table 3, was carried out following the same methodology of the SB Brazil with the aim of comparing national and local indicators.

In the present study, to know the self-perception that the elderly have on oral health, we also applied the same questionnaire used in the SB Brazil. Each elderly selected of the CG1 (Federal University of Ceará) and CG2 (University of Fortaleza) answered to the self-perception questionnaire that contained some questions as "classify your oral health; classify the appearance of your teeth and gums; the effect of their oral health in social relations; and your experience of dental pain in the last six months”, showed in the Table 3. The choice of this questionnaire was based on standardization of the information, considering that it was an instrument to collect data endorsed by two epidemiological surveys, one national and one local.

Calibration of the research team occurred prior to data collection. Inter-rater error was measured by Kappa concordance statistical analysis [15], resulting in values of 0.89 for decay, 0.67 for CPI, 0.74 for LA, 0.88 for denture use and 0.86 in the need of prosthesis. Concordance percentages were determined as $93.1 \%$ (decay), 79\% (CPI), 83\% (LA), 96\% (use) and 86.8\% (need). These were considered as optimal, moderate, good, excellent and very good, respectively.

Oral examinations were performed in a large, naturally lit area. Elderly subjects were seated with their heads resting backwards and the examiner standing in front of them. Sterilized material was used, consisting of a flat dental mirror, periodontal probe (WHO standard) and dental tweezers, as well as wooden spatulas, gloves, caps and disposable masks.

Charts were analyzed and data processed using Statistical Package for Social Science 16.0 software, with a $5 \%$ margin of error or significance level applied in statistical tests. All data obtained in the present study require reflexive analysis on the issue in question, supported by the literature on this topic.

The study was approved by the Ethical Review Board of the Federal University of Ceará. Only participants who signed informed written consent were examined. In the case of illiterate participants or those unable to sign, the terms were read in the presence of a witness and a right index fingerprint was taken.

\section{Results}

Of the 102 elderly subjects examined, 50 (49\%) participated in the CG1 and 52 (51\%) in the CG2. Mean age was 69.9 years (range: 60 - 86) and predominant age range was 60 - 65 years (30.4\%). Of the total, $84(82.4 \%)$ were women and $18(17.6 \%)$ were men.

Regarding marital status, $42(41.2 \%)$ were widows or widowers. A low education level was observed as 36 (35.3\%) considered themselves illiterate and only one participant reported completing university education.

According to the Standard Criteria of Economical Classification Brazil/2008 [12], 61.8\% from the sample was from class D (monthly income of $\mathrm{R} \$ 484.87$ ). When questioned about their place of residence, $82.4 \%$ stated they owned their own home.

Only 11 subjects $(10.8 \%)$ were smokers. Of these, most smoked cigarettes $(9.8 \%)$ four or more times a day (6.9\%). Ninety-nine participants (97.1\%) reported they did not consume alcohol.

Edentulism was observed in 65 subjects (63.7\%). A total of 69 presented a mean DMFT of 32, meaning they had not a single healthy tooth.

Of the 3264 teeth that should have been present in participants' mouths at the time of examination, 2964 (90.8\%) had been lost, leaving only 300 (9.2\%). Of these, 187 (62.3\%) were healthy, 10 (3.3\%) were filled and 103 (34.4\%) decayed. The mean DMFT index of subjects was recorded at an elevated value of 30.17, with a higher share of missing components (29.06). In relation to the total number of teeth present, individual mean was established at 2.94 with healthy status the most prevalent (1.83) (Table 1).

The 37 elderly individuals (36.27\%) with at least one tooth required some type of treatment. From the total of 105 teeth, 49 (46.6\%) needed restoration on one dental surface and 17 (16.2\%) on two or more surfaces. Thus, $34(32.4 \%)$ of these teeth required extraction and 5 (4.8\%), pulp treatment. Crowns, veneers, sealants or remineralization of white spot lesions were not needed. 
Table 1. Dental status of 102 elderly individuals aged 60 or older, from two community groups, Fortaleza, Ceará State, 2013.

\begin{tabular}{cccc}
\hline Dental status & Number of teeth $^{*}$ & $\%$ & Mean per individual $^{* *}$ \\
\hline Missing teeth & 2.964 & 90.8 & 29.06 \\
Teeth present & $\mathbf{3 0 0}$ & $\mathbf{9 . 2}$ & $\mathbf{2 . 9 4}$ \\
Healthy teeth & 187 & 62.3 & 1.83 \\
Decayed teeth & 91 & 30.4 & 0.89 \\
Filled teeth & 10 & 3.3 & 0.10 \\
Filled/decayed teeth & 12 & 4.0 & 0.12 \\
Total & $\mathbf{3 0 0}$ & $\mathbf{1 0 0}$ & $\mathbf{2 . 9 4}$ \\
\hline
\end{tabular}

${ }^{*}$ Total teeth $(\mathrm{n}=3264) ;{ }^{* *}$ of the total sample $(\mathrm{n}=102)$.

Thirty-six individuals had 270 (90\%) teeth with exposed roots, of which 47 (17.41\%) were decayed or filled and 223 (82.59\%) healthy.

With respect to prosthesis use (total or removable), Table 2 demonstrates that 30 (29.4\%) subjects did not use upper dentures and 69 (67.6\%) did not wear lower ones. In relation to necessity of use, 68 (66.7\%) needed some type of upper prosthesis while $80(78.4 \%)$ required lower prosthesis.

Periodontal status was evaluated in only $70(11.44 \%)$ sextants of 30 individuals. This is because 542 sextants (88.5\%) were excluded for displaying less than two teeth present. According to CPI, just 5 (7.14\%) sextants were healthy, with dental calculus most frequent, observed in 31 (44.29\%) of these individuals. Shallow periodontal pockets (4 to $5 \mathrm{~mm}$ ) occurred in 18 (25.71\%) sextants. Gingival bleedings after probing and deep pockets (6 mm or more) were less common. LA ranging from 6 to $8 \mathrm{~mm}$ predominated and was found in 24 (34.8\%) sextants. LA measuring $12 \mathrm{~mm}$ or more was recorded in only one sextant.

Research to determine the existence or absence of soft tissue alterations found these were present in 60 (58.8\%) subjects.

Of the 102 individuals undergoing clinical examination and responding to the survey on self-perception, 2 (2\%) rated their oral health as "terrible", 20 (19.6\%) as "bad", 16 (15.7\%) as "normal", 50 (49\%) as "good" and $9(8.8 \%)$ as "excellent".

Subjective health-related conditions that remained associated with positive oral health among the elderly were: reports of no pain over the preceding six months: 78 (76.5\%); positive assessment of chewing, speech and appearance of teeth and gums: 51 (50\%), 61 (59.8\%) and 62 (60.8\%), respectively; and social life not affected by oral health status 60 (58.8\%). Table 3 compares self-perception data on oral health in the elderly according to epidemiological surveys carried out in Brazil [4], Ceará State [16] and the two CG studied.

\section{Discussion}

Our results are restricted to subjects from the two participating CG and may not be generalized to represent the entire population of Fortaleza, Ceará State, Brazil.

Demographic characteristics of the elderly individuals are in accordance to those found by Borges et al. [17], with a predominance of women and widows. The dominant age range, 60 to 65 years (30.4\%), and low education level are similar to the findings of Bulgarelli et al. [18].

The socioeconomic profile of the two groups was determined using the new Standard Criteria of Economic Classification Brazil/2008 [12], a scale based on the assets, material possessions and schooling of the head of the family. More than half of the subjects (61.8\%) were considered class D, followed by classes C2 (25.5\%), E (6.9\%), C1 (3.9\%) and B1 and B2 (1\% for both). Other studies have classified social status, however, comparison with the present study is not viable since different categorization is applied here as a result of the updated criteria [12].

Results from the indicators used do not differ from those found by other authors [19] [20], where DMFT and the percentage of edentulous subjects are high, with few teeth present in the oral cavity. Similarly to our study and those cited above, the largest percentage was women with a mean age over 60 years.

The present study found a higher DMFT (30.17) than that found in 2003 in the national survey (SB Brazil) [4] [14]. The latter examined 5349 elderly individuals between 65 and 74 years old and established a DMFT of 27.8. 
Table 2. Frequency distribution of prostheses use and needs in the upper and lower arch of 102 elderly individuals aged 60 or older, from two community groups Fortaleza, Ceará State, 2013.

\begin{tabular}{|c|c|c|c|c|}
\hline \multirow{2}{*}{ Prostheses Dental Use and Needs } & \multicolumn{2}{|c|}{ Upper Arch } & \multicolumn{2}{|c|}{ Lower Arch } \\
\hline & $\mathrm{n}$ & $\%$ & $\mathrm{n}$ & $\%$ \\
\hline \multicolumn{5}{|l|}{ Use and type of prosthesis } \\
\hline Those that do not wear prosthesis & 30 & 29.4 & 69 & 67.6 \\
\hline Prostheses users & 72 & 70.6 & 33 & 32.4 \\
\hline Partial removable prosthesis & 5 & 4.9 & 1 & 1 \\
\hline One or more fixed prosthesis and one or more partial removable prosthesis & - & - & 1 & 1 \\
\hline Complete prosthesis & 67 & 65.7 & 31 & 30.4 \\
\hline \multicolumn{5}{|l|}{ Need for and type of prosthesis } \\
\hline No need & 34 & 33.3 & 22 & 21.6 \\
\hline Existing need & 68 & 66.7 & 80 & 78.4 \\
\hline Requiring a prosthesis (fixed or removable)—-two or more elements & 1 & 1 & - & - \\
\hline Requiring a combination (PRD and PFD)_-one and/or more elements & 11 & 10.8 & 26 & 25.5 \\
\hline Requiring total prosthesis & 56 & 54.9 & 54 & 52.9 \\
\hline
\end{tabular}

In both studies the missing component was the largest index value: 92.9\% in SB Brazil and 90.8\% in CG1 and CG2. The SB Ceará [16] was conducted in Ceará State using similar methodology, evaluated 621 elderly participants and found a DMFT of 28.35, with a high share (27.01) of missing components.

Prevalence of edentulism reached 63.7\%, similar to research carried out in Botucatu, São Paulo State [20]. When compared to international results, the value is even higher number. In a study of 301 elderly individuals in Lithuania [21], only $11 \%$ of the sample was completely edentulous, with a mean DMFT of 21.7. In another study in the Chinese province of Guangdong [22], a DMFT of 14.7 was found among elderly urban inhabitants. In 2004, an investigation in an urban colony of India [23] assessed 1240 elderly inhabitants. Of these, only 188 were entirely edentulous.

When comparing the data obtained with the oral health status of the institutionalized aged in Brazil, we found that studies in Goiânia, Goiás State [10] and Fortaleza, Ceará State, Brazil [19] produced DMFT of 30.2 and 29.7, respectively. The missing component was the largest contributor to these high indices. Despite confirming that the institutionalized elderly exhibit greater chances of edentulism, this data indicate similar oral health status in the sample. This demonstrates that institutionalization is not a causal factor in the deterioration of oral health in this group [24].

In 2007, Martins et al. [3] found low demand for dental services in both elderly dentate and edentulous individuals. Absence of pain was determined as the main reason for lack of routine use in both groups. This confirms that, as well as an accumulation in demand over a lifetime, the need for these services only occurs in critical situations.

In the present study, $90 \%$ of teeth exhibited exposed root surfaces due to gingival recession. This produces an area of accumulated plaque and consequently, greater risk of developing caries. However, a substantial majority of exposed roots were healthy (82.6\%), in accordance with studies conducted in retirement homes [21].

From the 105 teeth present, 46.6\% required dental surface restoration. This differs from numbers found in other studies [20] [25], where the predominant treatment need was dental extraction followed by surface restoration.

Similarly to other Brazilian studies, edentulism was prevalent in both the upper and lower jaw [18] [19]. Denture usage was greater in the upper than the lower arch as established in the Brazilian Northeast [4] and in Ceará State [16] epidemiological surveys.

The identified need for prosthesis was in accordance to the findings in SB Ceará [16], where the percentage of individuals needing any type of upper denture was lower than that of lower dentures. However, values differed from those observed in the Brazilian Northeast [4] when investigating only the need for complete dentures. The sample exhibited a larger percentage (54.9\%) for the upper arch and slightly smaller (52.9\%) for the lower arch.

The percentage of invalid sextants was high (88.56\%) due to the significant number of edentulous individuals, 
Table 3. Self-perception of oral health in accordance with data from the SB Brazil, SB Ceará and the two community groups, Fortaleza, Ceará State, 2013.

\begin{tabular}{|c|c|c|c|c|c|c|}
\hline \multirow{2}{*}{ Self-Perception of Oral Health } & \multicolumn{2}{|c|}{ SB Brazil } & \multicolumn{2}{|c|}{ SB Ceará } & \multicolumn{2}{|c|}{ G1 and G2 } \\
\hline & $\mathrm{n}$ & $\%$ & $\mathrm{n}$ & $\%$ & $\mathrm{n}$ & $\%$ \\
\hline \multicolumn{7}{|l|}{ Classification of oral health } \\
\hline Do not know/did not answer & 318 & 5.96 & 37 & 6.09 & 5 & 4.9 \\
\hline Terrible & 250 & 4.69 & 13 & 2.14 & 2 & 2.0 \\
\hline Bad & 620 & 11.63 & 79 & 12.99 & 20 & 19.6 \\
\hline Normal & 1465 & 27.48 & 138 & 22.70 & 16 & 15.7 \\
\hline Good & 2452 & 45.99 & 333 & 54.77 & 50 & 49.0 \\
\hline Excellent & 227 & 4.26 & 8 & 1.32 & 9 & 8.8 \\
\hline \multicolumn{7}{|c|}{ Classification of the appearance of teeth and gums } \\
\hline Do not know/did not answer & 489 & 9.18 & 104 & 17.11 & 1 & 1.0 \\
\hline Terrible & 268 & 5.03 & 17 & 2.80 & 5 & 4.9 \\
\hline Bad & 730 & 13.70 & 91 & 14.97 & 17 & 16.7 \\
\hline Normal & 1431 & 26.86 & 129 & 21.22 & 15 & 14.7 \\
\hline Good & 2253 & 42.29 & 264 & 43.42 & 62 & 60.8 \\
\hline Excellent & 157 & 2.95 & 264 & 43.42 & 62 & 60.8 \\
\hline \multicolumn{7}{|l|}{ Classification of mastication } \\
\hline Do not know/did not answer & 208 & 3.90 & 30 & 4.93 & - & - \\
\hline Terrible & 372 & 6.98 & 53 & 8.72 & 16 & 15.7 \\
\hline Bad & 918 & 17.22 & 113 & 18.59 & 20 & 19.6 \\
\hline Normal & 1256 & 23.56 & 138 & 21.22 & 12 & 11.8 \\
\hline Good & 2377 & 44.58 & 269 & 44.24 & 51 & 50.0 \\
\hline Excellent & 201 & 3.77 & 5 & 0.82 & 3 & 2.9 \\
\hline \multicolumn{7}{|c|}{ Classification of speech due to teeth and gums } \\
\hline Do not know/did not answer & 335 & 6.28 & 82 & 13.49 & - & - \\
\hline Terrible & 176 & 3.30 & 17 & 2.80 & 1 & 1.0 \\
\hline Bad & 561 & 10.52 & 82 & 13.49 & 27 & 1.0 \\
\hline Normal & 1129 & 53.64 & 122 & 20.07 & 8 & 7.8 \\
\hline Good & 2860 & 53.64 & 300 & 49.34 & 61 & 59.8 \\
\hline Excellent & 271 & 5.08 & 5 & 0.82 & 5 & 4.9 \\
\hline \multicolumn{7}{|l|}{ Effect of health on social relationships } \\
\hline Do not know/did not answer & 702 & 13.17 & 85 & 14.53 & 2 & 2.0 \\
\hline No effect & 3334 & 62.53 & 371 & 63.42 & 60 & 58.8 \\
\hline Little effect & 672 & 12.60 & 80 & 13.68 & 21 & 20.6 \\
\hline Moderate effect & 330 & 6.19 & 29 & 4.96 & 9 & 8.8 \\
\hline Significant effect & 294 & 5.51 & 20 & 3.42 & 10 & 9.8 \\
\hline \multicolumn{7}{|c|}{ Amount of pain experienced in the last 6 months } \\
\hline No pain & 4134 & 77.56 & 467 & 80.66 & 78 & 76.5 \\
\hline Little pain & 704 & 13.21 & 64 & 11.05 & 15 & 14.7 \\
\hline Moderate pain & 249 & 4.67 & 24 & 4.15 & 3 & 2.9 \\
\hline Significant pain & 243 & 4.56 & 24 & 4.15 & 6 & 5.9 \\
\hline
\end{tabular}


in correlation with other reported data [11] [20]. This indicates possible service failures for this age group, as well as predominant mutilating dental care [6].

A greater percentage of the aged displayed LA of 6 to $8 \mathrm{~mm}$ (60\%), similar to findings in institutionalized elderly in Belo Horizonte, Minas Gerais State [17], remaining teeth suffered severe periodontal damage. This scenario, associated with lack of care and access to dental services, implies a prognosis of dental extraction.

Soft tissue alteration (present or absent) [14] was diagnosed in 58.8\% of the elderly individuals examined, higher than that found in Goiânia, Goiás State [10] (13.49\%). Surveys conducted in 2003 [4] and 2004 [16], although including this type of evaluation, did not present results, thereby making comparative analysis unfeasible.

In spite of the precarious clinical oral health conditions of CG members, self-perception seems incompatible since edentulism affected more than half the sample and even the teeth present needed some type of treatment. Other national studies [7] [17] also showed predominance of positive oral health perception.

Silva et al. [8] assessed self-perception of oral health using the Geriatric Oral Health Assessment Index (GOHAI), which evaluates the impact of oral disease on the aged. Satisfactory oral health perception contrasted with clinical conditions, which were characterized by high edentulism rates.

The present study found the same pattern of factual results and divergent self-perceptions in regard to the appearance of teeth and gums. Although $63.7 \%$ of elderly individuals were completely edentulous, $60.8 \%$ rated this element as good. Other studies [6] [8] [25] also report this same divergence between dental status and selfperception of oral health. This suggests that the elderly may not view edentulism as a problem.

Additionally, it is important to note that individuals in this study reported satisfaction with their phonation, as did subjects between 65 and 74 examined in SB Brazil [4] and SB Ceará [16]. Speech was classified as good due to teeth and gums for $59.8 \%, 53.64 \%$ and $49.34 \%$, respectively.

Most elderly people do not consider that missing teeth compromise chewing, as 50\% rated it as good. Reduced masticatory capacity does not seem to be felt by the elderly, owing to diet adaptations and denture use, even though this condition does not permit adequate chewing. This phenomenon was reported as a deficiency by some individuals who underwent prosthetic oral rehabilitation [26].

The influence of oral status on social relationships was confirmed by $39.2 \%$ of elderly people. Moreira, Nico and Sousa [27] analyzed factors associated to subjective dental treatment needs and found that those reporting this aspect showed greater frequency of perceived need for restorative or rehabilitative procedures.

Of the total sample, $76.5 \%$ stated they felt no pain in their teeth in the preceding 6 months. Martins, Barreto and Pordeus [28] assessed 2928 aged subjects and found that self-evaluation of treatment needs was higher among those with pain in the 6 months preceding the study. A frequent positive association was reported between pain and self-perception of treatment needs, confirming a demand for dental services only in critical situations [3].

There are a growing number of studies involving self-perception of oral health, particularly regarding tooth loss and its associated psychological, social and functional aspects. Regular dental treatment and collective health promotion would likely maintain the elderly population informed and provide sufficient knowledge for a real evaluation of their treatment needs, influencing their behavior in relation to quality of life.

It is important to emphasize the significance of epidemiology as an essential tool in the planning and application of preventive, curative, educational and rehabilitative measures, as well as in guiding public policy. This benefits chewing, phonation, swallowing and esthetics among the aged, thereby favoring improved health and quality of life.

Both the clinical and self-reported epidemiological data obtained in the population studies mentioned should be taken into account for effective organization of oral healthcare in the National Health System [29].

In 2004, the Ministry of Health and the National Oral Health Coordination published the "National Oral Health Policy Guidelines”. This produced wide-ranging discussions with State oral health coordinators, proposals in congresses, dental and collective health meetings, as well as deliberations in National Health Conferences and the First and Second National Oral Health Conferences. The aim was to reorganize oral healthcare at all levels [30].

In this context, based on the National Oral Health Policy, the Ministry of Health launched the "Smiling Brazil" Program [31] in order to offer appropriate dental care to all Brazilians dependent on public healthcare. The aim was to guarantee and expand dental assistance to the elderly, minimizing service barriers for this sector of the population. Through the combination of several oral health measures such as prevention, diagnosis, treatment 
and rehabilitation, this program reorganizes the reference and cross-reference system, expanding basic and specialized care, as well as the number of Family Health Strategy teams.

According to Ministry of Health data, the "Smiling Brazil" Program [31] increased the population treated by 250\% between 2002 and 2009, significantly improving oral health conditions. The program also extended Regional Dental Prosthesis Laboratories, aiming to rehabilitate this dentally challenged population through opportunities and encouraging prospects of an effectively more radiant Brazil.

Elderly subjects from both CG, located on the outskirts of Fortaleza, Ceará State, Brazil, reported positive self-evaluations of their oral health, despite unsatisfactory clinical conditions (high DMFT, with greater participation of the missing component; need for some type of dental intervention in all remaining teeth; periodontal disease, presenting calculus, periodontal pockets and a significant prevalence of invalid sextants due to high edentulism rates). These findings reflect the need for implementation of rehabilitative oral health policies focusing on the elderly and based on the perspective of integrality as the primary doctrine in the National Health System. This would result in better quality of life, not only because of improved chewing, digestion and greater appreciation of food, but also in favoring the socialization and self-esteem of these individuals.

\section{Conclusion}

Elderly subjects from both CG, located on the outskirts of Fortaleza, Ceará State, Brazil, reported positive self-evaluations of their oral health, despite unsatisfactory clinical conditions (high DMFT, with greater participation of the missing component; need for some type of dental intervention in all remaining teeth; periodontal disease, presenting calculus, periodontal pockets and a significant prevalence of invalid sextants due to high edentulism rates). These findings reflect the need for implementation of rehabilitative oral health policies focusing on the elderly and based on the perspective of integrality as the primary doctrine in the National Health System. This would result in better quality of life because of improved chewing, digestion and greater appreciation of food, and in favoring the socialization and self-esteem of these individuals.

\section{Acknowledgements}

These authors are grateful to the participants of Grey Smile Project (Projeto Sorriso Grisalho) from the Federal University of Ceará, to the elderly, their companions and caregivers, as well as the coordinators of the two community groups. We would also like to thank Prof. Dr. Léa Maria Bezerra da Menezes for her relevant contribution in the critical revision of intellectual content and continued support of the project.

\section{References}

[1] Barreto, S.M., Giatti, L. and Kalache, A. (2004) Gender Inequalities in Health among Older Brazilian Adults. Revista Panamericana de Salud Pública, 16, 110-117. http://dx.doi.org/10.1590/S1020-49892004000800006

[2] Colussi, C.F. and Freitas, S.F.T. (2002) Aspectos epidemiológicos da saúde bucal do idoso no Brasil. Cadernos de Saúde Pública, 18, 1313-1320. http://dx.doi.org/10.1590/S0102-311X2002000500024

[3] Martins, A.M.E.B.L., Barreto, S.M. and Pordeus, I.A. (2007) Uso de serviços odontológicos entre idosos brasileiros. Revista Panamericana de Salud Pública, 22, 425-430. http://dx.doi.org/10.1590/S1020-49892007001000003

[4] Departamento de Atenção Básica, Secretaria de Atenção à Saúde, Ministério da Saúde, Brasil (2014) Projeto SB Brasil 2003: Condições de saúde bucal da população brasileira 2002-2003: Resultados principais. Ministério da Saúde, Brasília.

[5] World Health Organization (1997) Oral Heath Surveys: Basic Methods. 4th Edition, World Health Organization, Geneva.

[6] Narvai, P.C. and Antunes, J.L.F. (2003) Saúde bucal: A autopercepção da mutilação e das incapacidades. In: Lebrão, M.L. and Duarte, Y.A.O., Org., SABE-Saúde, Bem-estar e Envelhecimento. O projeto SABE no Município de São Paulo: Uma abordagem inicial, Organização Pan-Americana da Saúde, Brasília, 121-137.

[7] Heft, M.W., Gilbert, G.H., Shelton, B.J. and Duncan, R.P. (2003) Relationship of Dental Status, Sociodemographic Status, and Oral Symptoms to Perceived Need for Dental Care. Community Dentistry and Oral Epidemiology, 31, 351360. http://dx.doi.org/10.1034/j.1600-0528.2003.00014.x

[8] Silva, S.R.C. and Fernandes, R.A.C. (2001) Autopercepção das condições de saúde bucal por idosos. Revista de Saúde Pública, 35, 349-355. http://dx.doi.org/10.1590/S0034-89102001000400003

[9] Sheiham, A. and Watt, R.G. (2000) The Common Risk Factor Approach: A National Basis for Promoting Oral Health. Community Dentistry and Oral Epidemiology, 28, 399-406. http://dx.doi.org/10.1034/j.1600-0528.2000.028006399.x

[10] Reis, S.C.G.B. and Marcelo, V.C. (2006) Saúde bucal na velhice: Percepção dos idosos, Goiânia, 2005. Ciência \& 
Saúde Coletiva, 11, 191-199. http://dx.doi.org/10.1590/S1413-81232006000100028

[11] Fédération Dentaire Internationale (FDI) (1987) Oral Needs of the Elderly. Commission on Oral Health. FDI Research and Epidemiology Working Group 5, FDI, Amsterdam.

[12] Associação Brasileira de Empresas de Pesquisa ABEP (2007) Critério Padrão de Classificação Econômica Brasil/2008. ABIPEME.

[13] Área Técnica de Saúde Bucal, Departamento de Atenção Básica, Secretaria de Políticas de Saúde, Ministério da Saúde, Brasil (2001) Projeto SB 2000: Condições de saúde bucal da população brasileira no ano 2000: Manual do examinador. Ministério da Saúde, Brasília.

[14] Roncalli, A.G., Silva, N.N., Nascimento, A.C., Freitas, C.H., Casotti, E., Peres, K.G., et al. (2012) Relevant Methodological Issues from the SB Brasil 2010 Project for National Health Surveys. Cadernos de Saúde Pública, 28, S40-S57.

[15] Frias, A.C. (2000) Estudo de confiabilidade do levantamento epidemiológico de saúde bucal, Estado de São Paulo 1998. Dissertação de Mestrado, Faculdade de Saúde Pública, Universidade de São Paulo, São Paulo.

[16] Secretaria de Saúde do Estado, Ceará (2004) Levantamento epidemiológico em saúde bucal do Estado do Ceará—SB Ceará: Resultados finais. Secretaria de Saúde do Estado do Ceará, Fortaleza.

[17] Borges, P.L.C., Bretas, R.P., Azevedo, S.F. and Barbosa, J.M.M. (2008) Perfil dos idosos frequentadores de grupos de convivência em Belo Horizonte, Minas Gerais, Brasil. Cadernos de Saúde Pública, 24, 2798-2808. http://dx.doi.org/10.1590/S0102-311X2008001200008

[18] Bulgarelli, A.F., Pinto, I.C., Rodrigues Junior, A.L. and Manco, A.R.X. (2009) Estudo das Queixas sobre Saúde Bucal em uma População de Idosos na Cidade de Ribeirão Preto-São Paulo. Revista Brasileira de Geriatria e Gerontologia, 12, 175-191.

[19] Silva, D.D., Rihs, L.B. and Sousa, M.L.R. (2009) Factors Associated with Remaining Teeth of Elderly in the State of São Paulo, Brazil, 2002. Gerodontology, 26, 282-290.

[20] Gaião, L.R., Almeida, M.E.L. and Heukelbach, J. (2005) Perfil epidemiológico da cárie dentária, doença periodontal, uso e necessidade de prótese em idosos residentes em uma instituição na cidade de Fortaleza, Ceará. Revista Brasileira de Epidemiologia, 8, 316-323. http://dx.doi.org/10.1590/S1415-790X2005000300013

[21] Aleksejuniene, J., Holst, D. and Eriksen, H.M. (2000) Patterns of Dental Caries and Treatment Experience in Elderly Lithuanians. Gerodontology, 17, 77-86. http://dx.doi.org/10.1111/j.1741-2358.2000.00077.x

[22] Lin, H.C., Wong, M.C., Zhang, H.G., Lo, E.C. and Schwarz, E. (2001) Coronal and Root Caries in Southern Chinese Adults. Journal of Dental Research, 80, 1475-1479. http://dx.doi.org/10.1177/00220345010800051801

[23] Shah, N. and Sundaran, K.R. (2004) Impact of Socio-Demographic Variables, Oral Hygiene Practices, Oral Habits and Diet on Dental Caries Experience of Indian Elderly: A Community-Based Study. Gerodontology, 21, 43-50. http://dx.doi.org/10.1111/j.1741-2358.2004.00010.x

[24] Slade, G.D., Locker, D., Leake, J.L., Price, S.A. and Chao, I. (1990) Differences in Oral Health Status between Institutionalized and Non-Institutionalized Older Adults. Community Dentistry and Oral Epidemiology, 18, 272-286. http://dx.doi.org/10.1111/j.1600-0528.1990.tb00076.x

[25] Área Técnica de Saúde Bucal, Departamento de Atenção Básica, Secretaria de Políticas de Saúde, Ministério da Saúde, Brasil (2000) Projeto SB 2000: Condições de saúde bucal da população brasileira no ano 2000. Ministério da Saúde, Brasília.

[26] Benedetti, T.R.B., Mello, A.L.S.F. and Gonçalves, L.H.T. (2007) Idosos de Florianópolis: Autopercepção das condições de saúde bucal e utilização de serviços odontológicos. Ciência \& Saúde Coletiva, 12, 1683-1690. http://dx.doi.org/10.1590/S1413-81232007000600029

[27] Moreira, R.S., Nico, L.S. and Sousa, M.L.R. (2009) Fatores associados à necessidade subjetiva de tratamento odontológico em idosos brasileiros. Cadernos de Saúde Pública, 25, 2661-2671. http://dx.doi.org/10.1590/S0102-311X2009001200013

[28] Martins, A.M.E.B.L., Barreto, S.M. and Pordeus, I.A. (2008) Fatores relacionados à autopercepção da necessidade de tratamento odontológico entre idosos. Revista de Saúde Pública, 42, 487-496. http://dx.doi.org/10.1590/S0034-89102008000300014

[29] Narvai, P.C., Antunes, J.L.F., Moysés, S.J., Frazão, P., Peres, M.A., Peres, K.G., et al. (2010) Validade científica de conhecimento epidemiológico gerado com base no estudo Saúde Bucal Brasil 2003. Cadernos de Saúde Pública, 26, 647-670. http://dx.doi.org/10.1590/S0102-311X2010000400002

[30] Coordenação Nacional de Saúde Bucal, Departamento de Atenção Básica, Secretaria de Atenção à Saúde, Ministério da Saúde, Brasil (2004) Diretrizes da Política Nacional de Saúde Bucal. Ministério da Saúde, Brasília.

[31] Ministério da Saúde, Brasil (2011) Brasil Sorridente: A saúde levada a sério. www.saude.gov.br 
Scientific Research Publishing (SCIRP) is one of the largest Open Access journal publishers. It is currently publishing more than 200 open access, online, peer-reviewed journals covering a wide range of academic disciplines. SCIRP serves the worldwide academic communities and contributes to the progress and application of science with its publication.

Other selected journals from SCIRP are listed as below. Submit your manuscript to us via either submit@scirp.org or Online Submission Portal.
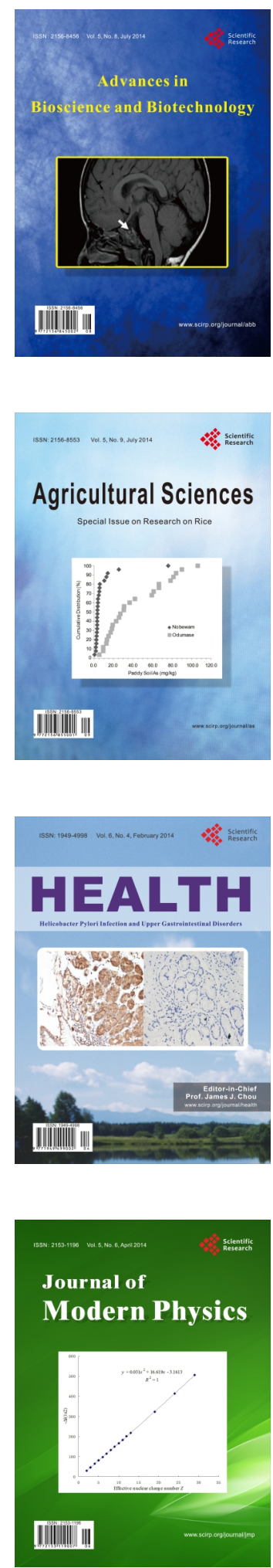
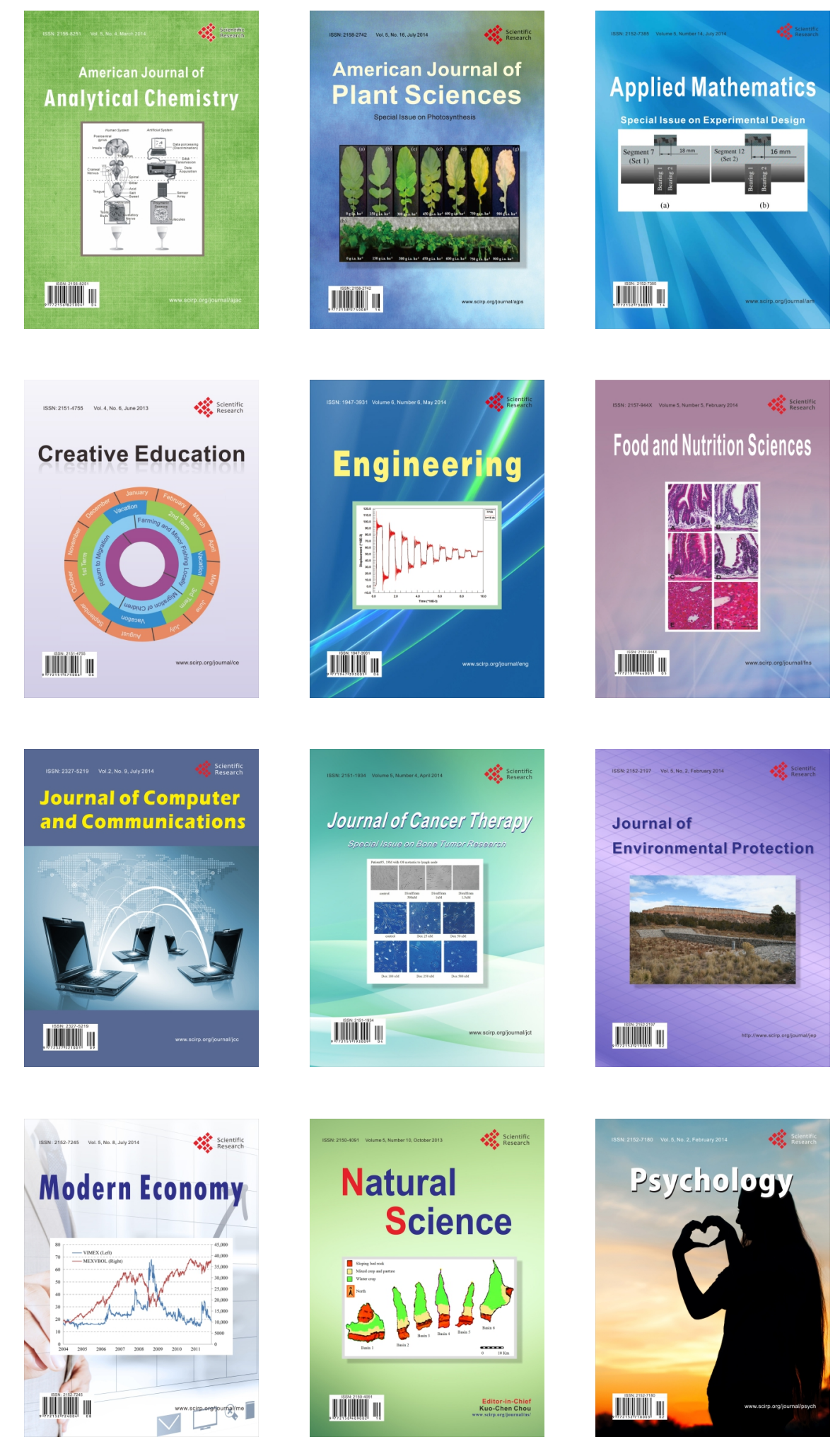